\title{
A new and convenient synthetic way to 2-substituted thieno[2,3-b]indoles
}

\author{
Roman A. Irgashev ${ }^{* 1,2}$, Arseny A. Karmatsky ${ }^{1,2}$, Gennady L. Rusinov ${ }^{1,2}$ \\ and Valery N. Charushin 1,2
}

\author{
Full Research Paper \\ Address: \\ ${ }^{1}$ Postovsky Institute of Organic Synthesis, Ural Division of the \\ Russian Academy of Sciences, Ekaterinburg, 620990, Russia and \\ 2Ural Federal University named after the First President of Russia, B. \\ N. Yeltsin, Ekaterinburg, 620002, Russia \\ Email: \\ Roman A. Irgashev* - irgashev@ios.uran.ru \\ * Corresponding author \\ Keywords: \\ aldol-crotonic condensation; isatin; Lawesson's reagent; methyl \\ ketones; Paal-Knorr reaction; thieno[2,3-b]indole
}

Beilstein J. Org. Chem. 2015, 11, 1000-1007. doi:10.3762/bjoc. 11.112

Received: 19 March 2015

Accepted: 19 May 2015

Published: 11 June 2015

Associate Editor: J. P. Wolfe

(c) 2015 Irgashev et al; licensee Beilstein-Institut. License and terms: see end of document.

\begin{abstract}
A short and robust approach for the synthesis of 2-(hetero)aryl substituted thieno[2,3-b]indoles from easily available 1-alkylisatins and acetylated (hetero)arenes has been advanced. The two-step procedure includes the "aldol-crotonic" type of condensation of the starting materials, followed by treatment of the intermediate 3-(2-oxo-2-(hetero)arylethylidene)indolin-2-ones with Lawesson's reagent. The latter process involves two sequential reactions, namely reduction of the $\mathrm{C}=\mathrm{C}$ ethylidene double bond of the intermediate indolin-2-ones followed by the Paal-Knorr cyclization, thus affording tricyclic thieno[2,3-b]indoles.
\end{abstract}

\section{Introduction}

$8 H$-Thieno[2,3-b]indole is a fused heterocyclic system, which has attracted a considerable attention of researchers, mainly due to the fact that thieno[2,3-b]indole derivatives exhibit a wide range of biological properties, and can be regarded as promising compounds for agricultural or pharmacological applications. For example, the alkaloid thienodolin [1], isolated from the fermentation mixture of Streptomyces albogriseolus and characterized by Kanbe et al. [2,3], has shown to exhibit a plantgrowth-regulation activity (Figure 1). Furthermore, it has been reported that some thienoindoles are therapeutically agents for treating diseases of the central nervous system [4], potential inhibitors of acetylcholine esterase and butyrylcholine esterase [5], compounds of this series exhibit as well anti-tuberculosis [6] and anti-inflammatory activities [7]. Another promising area for the use of thieno[2,3-b]indoles, as electron-rich heteroaromatics, is the design of photo- and electroactive compounds which can be applied in organic optoelectronic materials. Indeed, we have recently reported the synthesis of novel push-pull dyes IK-1,2 based on the thieno[2,3- $b$ ]indole ring system, as a donating part of dye-sensitized solar cells [8] (Figure 1). It should be noted that thieno[2,3-b]pyrrole and thieno[3,2-b]pyrrole ring systems have been incorporated in the 
structures of various fused polycyclic compounds (heteroacenes), which have been used as efficient hole-transport materials for organic light emitting diodes (OLEDs) or field effect transistors (OFETs) [9-15].

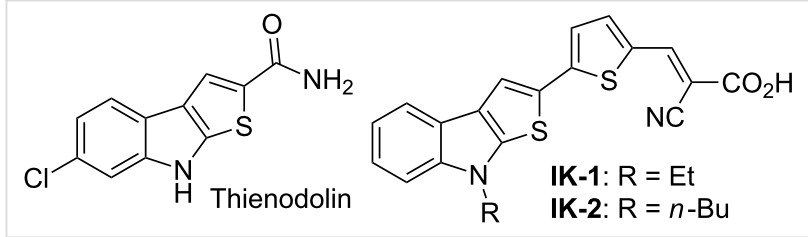

Figure 1: Natural and synthetic derivatives of thieno[2,3-b]indole.

Taking into account that the overwhelming majority of compounds for organic electronics are constructed from $\pi$-conjugated linear or angular fused aromatic and heteroaromatic units [16-19], the development of convenient synthetic ways to structures bearing several linked (het)aromatic units appears to be a very important issue. It means that synthetic methods should be based on a minimum number of steps (one-pot procedure as the perfect case), while the starting materials are supposed to be easily available.

A number of synthetic routes to thieno[2,3- $b]$ indoles have been described in the literature, including oxidative cyclization of indolin-2-thiones 1 [20], radical or palladium catalyzed cyclization of 3-(2-bromoindol-3-yl)acrylonitriles 2 [21,22], intramolecular $\mathrm{CH} / \mathrm{NH}$-coupling in benzo[b]thiophenes 3 [23], $\mathrm{AlCl}_{3}$ catalyzed recyclization of 2-(2-isothiocyanatophenyl)furanes 4 [24], reductive cyclization of 3-(2-nirtophenyl)thiophenes 5 via nitrene intermediates $[25,26]$, and condensation of 3-unsubsti- tuted indolin-2-thione 6 with aliphatic $\alpha$-bromoaldehydes, $\alpha$-bromoketones [27] or 3-halochromones $(\mathrm{Hlg}=\mathrm{Cl}, \mathrm{Br})$ [28] under basic conditions (Scheme 1). However, all synthetic methods mentioned above are based on using functionalized indoles, thiophenes, furans or chromone precursors, which require several steps to be prepared.

\section{Results and Discussion}

In this paper we wish to report a convenient, short and robust approach to 8 -alkyl-2-(het)arylthieno[2,3-b]indoles from 1 -alkylisatins and the corresponding acetylated (hetero)arenes which are easily accessible reagents, including commercially available ones. It is well known that the reaction of isatins 7 with methyl ketones $\mathbf{8}$ leads to the formation of aldol-type adducts 9 under catalysis with mild bases, such as secondary or tertiary amines. These adducts can be dehydrated easily by acidic agents to form crotonic condensation products, namely 3-(2-oxo-2-(hetero)arylethylidene)indolin-2-ones 10, which can undergo reduction of the $\mathrm{C}=\mathrm{C}$ double bond in the presence of $\mathrm{Na}_{2} \mathrm{~S}_{2} \mathrm{O}_{4}$ [29], $\mathrm{H}_{2} / \mathrm{Pd}(\mathrm{C})$ [30], or $\mathrm{Me}_{3} \mathrm{P}-\mathrm{H}_{2} \mathrm{O}$ [31] (Scheme 2) into the corresponding indolin-2-ones 11. Compounds 11 bearing the fragment of 4-oxobutyramides (1,4-dicarbonyl derivatives) can be cyclized into thieno[2,3-b]indoles by using the Paal-Knorr reaction with such thionation agents, as $\mathrm{P}_{4} \mathrm{~S}_{10}$ or Lawesson's reagent. This four-step route to thieno[2,3-b]indoles via the formation of indoline-2-ones 11 from isatins and methyl ketones has previously been realized $[32,33]$. In particular, preparation of 2-methyl- $8 H$-thieno[2,3- $b]$ indole from unsubstituted isatin and acetone in $15 \%$ yield has been reported [32] (Scheme 2). Although it seems to be a very harmonious strategy, it has hardly a significant preparative interest, since the

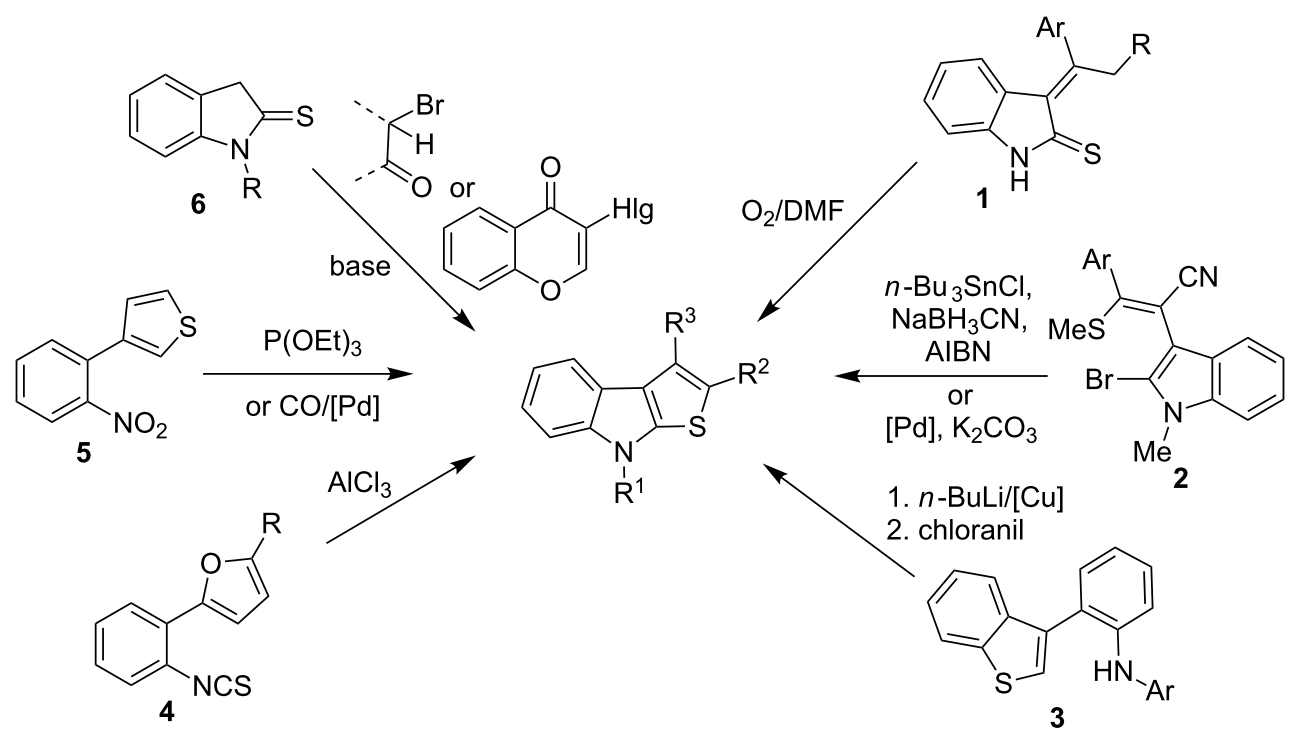




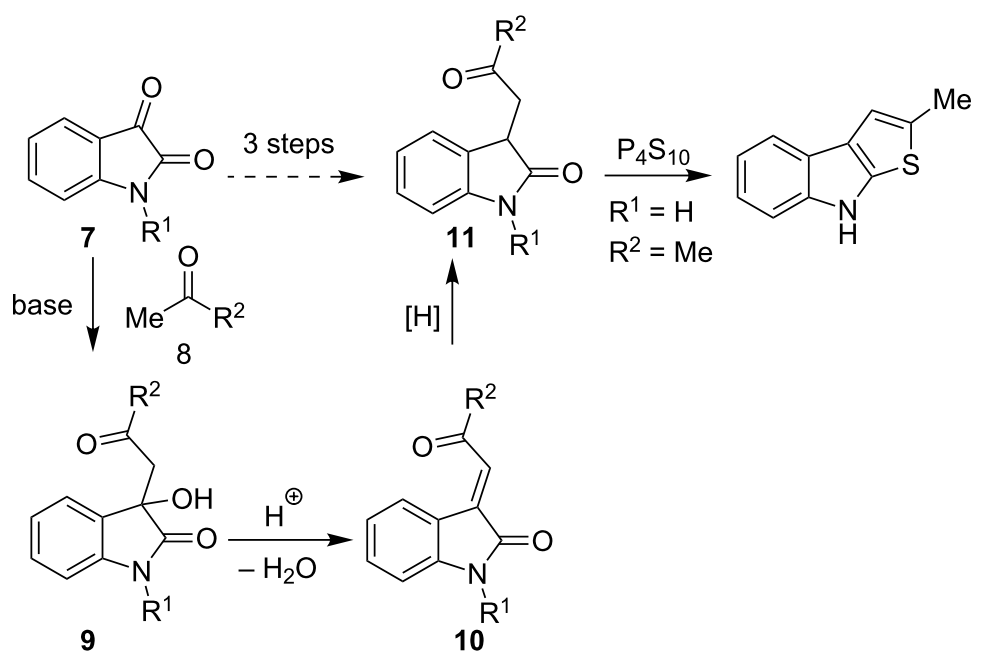

Scheme 2: Synthesis and thionation of indodin-2-ones 11.

target compounds are formed from isatins $\mathbf{7}$ and ketones $\mathbf{8}$ in four steps in low yields.

The formation of model thieno[2,3-b]indole 12a from 1-ethylisatin (7a) and acetophenone (8a) has been studied in details, as the first step of our research (Scheme 3). The conventional path [32] (Path C) leading to the aldol adduct 9a (which was further used without purification in all our experiments), its dehydra- tion into 10a, reduction of the latter to indolin-2-ones 11a, and finally cyclization of 11a by action of Lawesson's reagent (LR), resulting in the formation of the desired product $12 \mathrm{a}$ in an overall yield of $25 \%$. We have found that treatment of compound 10a with Lawesson's reagent in toluene solution under reflux for $1 \mathrm{~h}$ leads to $\mathbf{1 2 a}$ as well; however the best overall yield of $57 \%$ has only been reached (Path B). The evidence for the structure of 12a has been obtained unequivocally by X-ray

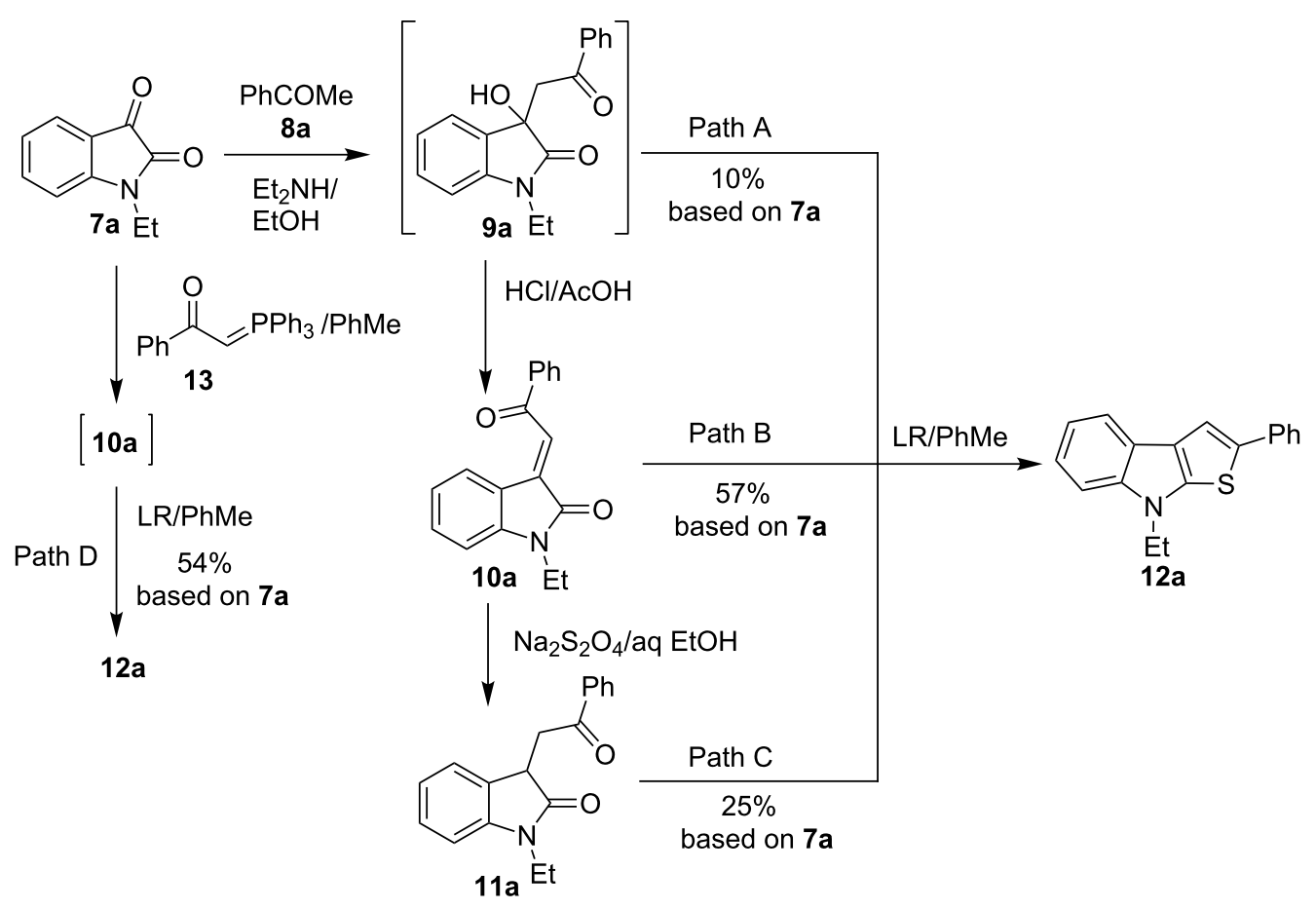

Scheme 3: Synthetic paths to thieno[2,3-b]indole 12a. LR = Lawesson's reagent 
crystallography analysis, thus supporting the data of ${ }^{1} \mathrm{H}$ and ${ }^{13}$ C NMR spectroscopy (Figure 2).

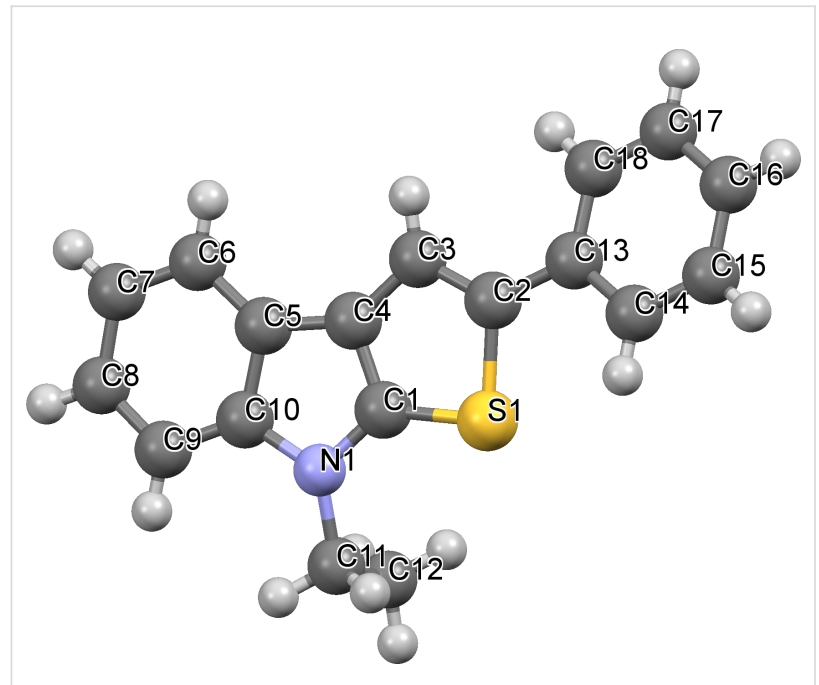

Figure 2: Mercury [34] representation of the X-ray crystal structure of 12a. Thermal ellipsoids of $50 \%$ probability are presented.

The Lawesson's reagent appears to act firstly as a source of hydrogen sulfide to reduce the $\mathrm{C}=\mathrm{C}$ double bond in compound 10a, and secondly, as the thiation agent to form thieno[2,3$b$ ]indole 12a by means of the Paal-Knorr reaction. Compound 9a has also been treated with the Lawesson's reagent in toluene to give the title product 12a via intermediacy of 10a in a low $10 \%$ yield, based on the starting isatin $7 \mathbf{a}$ (Path A). Also the one-pot synthesis (Path D) of compound 12a has been realized through treatment of isatin $\mathbf{7 a}$ with (phenacylidene)triphenylphosphorane $\mathbf{1 3}$ and subsequent cyclization of the intermediate 10a according the Path B. The yield of the target product 12a obtained by the one-port procedure proved to be close to that of 12a deriving from the Path $\mathrm{B}$. Path D requires the more expensive phosphorane derivative $\mathbf{1 3}$ which is formed by pre-functionalization of acetophenone (8a), and this approach can be regarded as an alternative synthetic route just in some specific cases. Thus, the two-step approach to convert isatins 7 into thieno[2,3-b]indoles $\mathbf{1 2}$ via intermediacy of $\mathbf{1 0}$ (Path B) has been selected as the most effective and convenient one.

Thereafter, a series of thieno[2,3-b]indoles 12a-m bearing both electron-rich and electron-deficient (hetero)aromatic fragments at $\mathrm{C}-2$ have been prepared in good to moderate yields via the two-step synthetic procedure (Path B, Scheme 3) from isatin 7a and the corresponding acetylated (hetero)arenes 8a-m. Dehydration of the initially obtained aldol-type adducts into 3-(2oxo-2-(hetero)arylethylidene)indolin-2-ones $\mathbf{1 0}$ has been carried out in acetic acid solution with addition of hydrochloric acid (method A), or in $\mathrm{CH}_{2} \mathrm{Cl}_{2}$ solution with an excess of $\mathrm{SOCl}_{2}$ (method B), when compounds $\mathbf{1 0}$ failed to be obtained by method A (Table 1, Scheme 4). It should be noted that thieno[2,3-b]indole derivatives $\mathbf{1 2 e}, \mathbf{f}$ bearing $4-\mathrm{CN}-$ or $2-\mathrm{NO}_{2}-$ phenyl substituents at $\mathrm{C}-2$ have been prepared in high yields from the appropriate indolin-2-ones $\mathbf{1 0 e , f}$ by treatment with Lawesson's reagent under the current reaction conditions without displacement of $\mathrm{CN}$ - or $\mathrm{NO}_{2}$-groups (Table 1, entries 5 and 6).

Additionally, compounds 12n,o bearing one or two bromine atoms at C-5 or C-5,7 of the thieno[2,3-b]indole scaffold have been prepared successfully from the corresponding isatins $\mathbf{7 b}, \mathbf{c}$ and acetophenone (8a) according to the synthetic procedure described above. Isatin 7c containing an $n$-hexyl substituent at the nitrogen atom has been applied to ensure a good solubility of the target product 12o, as well as of the intermediate 10o. It should be noted that bromination of 2-phenyl-substituted thieno[2,3- $b$ ]indole 12a led to a rather complicated mixture of compounds, and all attempts to reach bromination of compound 12a with an excess of $\mathrm{Br}$-agent (e.g., $\mathrm{Br}_{2} / 1$,4-dioxane, $\mathrm{NBS} / \mathrm{CHCl}_{3}$ ) proved to be unsuccessful (Scheme 5).

\section{Conclusion}

In summary, we have developed a convenient and robust synthetic approach to thieno[2,3- $b$ ]indoles, bearing a wide range of aromatic and heteroaromatic substituents at $\mathrm{C}-2$ with various

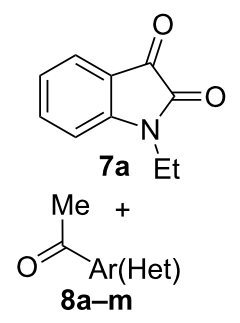

1. $\mathrm{Et}_{2} \mathrm{NH} / \mathrm{EtOH}, 48 \mathrm{~h}, \mathrm{rt}$

2. method $\mathrm{A}: \mathrm{HCl} / \mathrm{AcOH}, 0.5 \mathrm{~h}, \Delta$ or
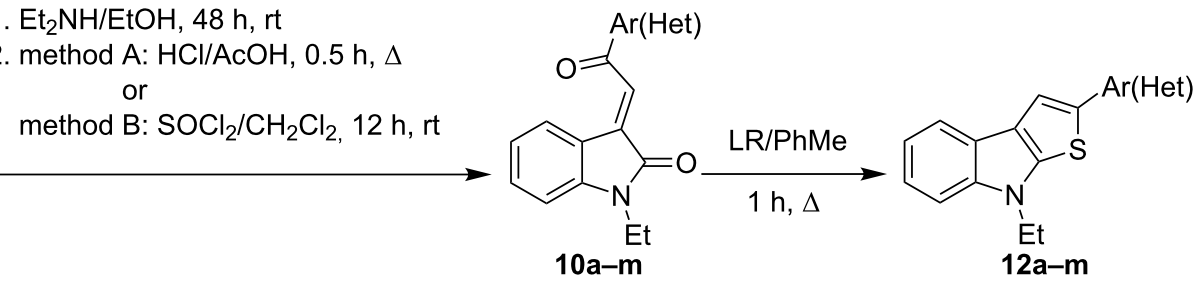


\begin{tabular}{|c|c|c|c|c|c|c|c|}
\hline Entry & Keton 8 & (Het)Ar & Method for 10 & Indolin-2-one 10 & Yield of $10(\%)$ & $\mathrm{T}[2,3-b] \mid 12$ & Yield of $12(\%)$ \\
\hline 1 & $8 a$ & $\mathrm{Ph}$ & $A$ & $10 a$ & 63 & $12 a$ & 90 \\
\hline 2 & $8 b$ & & $A$ & $10 \mathrm{~b}$ & 65 & $12 b$ & 90 \\
\hline 3 & $8 c$ & & A & $10 \mathrm{c}$ & 69 & $12 \mathrm{c}$ & 94 \\
\hline 4 & $8 d$ & & A & $10 d$ & 57 & $12 d$ & 79 \\
\hline 5 & $8 e$ & & B & $10 \mathrm{e}$ & 75 & $12 e$ & 92 \\
\hline 6 & $8 f$ & & $B$ & $10 f$ & 81 & $12 f$ & 82 \\
\hline 7 & $8 g$ & & A & $10 \mathrm{~g}$ & 74 & $12 \mathrm{~g}$ & 56 \\
\hline 8 & $8 \mathrm{~h}$ & & A & $10 \mathrm{~h}$ & 91 & $12 \mathrm{~h}$ & 70 \\
\hline 9 & $8 i$ & $\mathrm{C}_{6} \mathrm{~F}_{5}$ & $A$ & $10 i$ & 33 & $12 i$ & 77 \\
\hline 11 & $8 j$ & & $A$ & $10 \mathrm{j}$ & 76 & $12 \mathrm{j}$ & 75 \\
\hline 10 & $8 k$ & & $A$ & $10 \mathrm{k}$ & 76 & $12 k$ & 74 \\
\hline 12 & 81 & & B & 101 & 66 & $12 I$ & 61 \\
\hline 13 & $8 m$ & & B & $10 \mathrm{~m}$ & 67 & $12 m$ & 60 \\
\hline
\end{tabular}

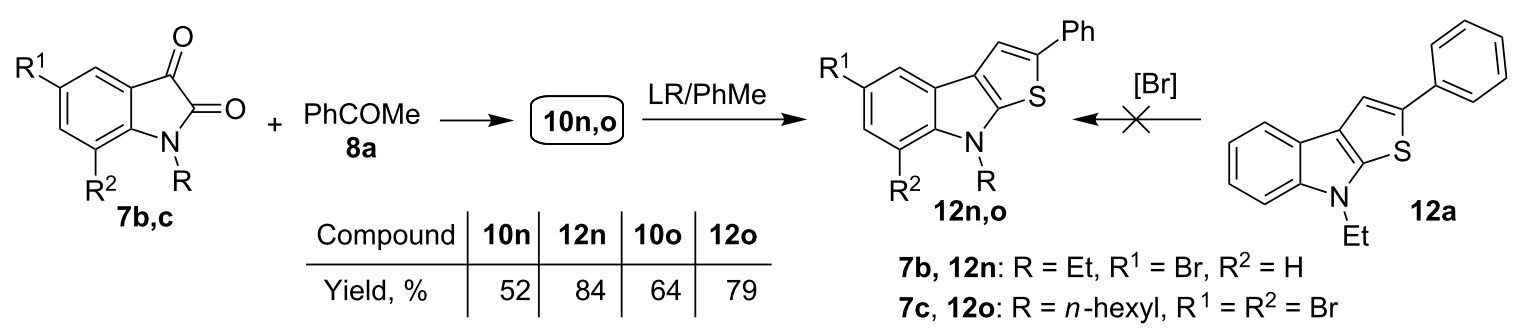

Scheme 5: Synthesis of mono- and dibromo-substituted thieno[2,3-b]indoles 12n,o.

electronic characteristics. Target thieno[2,3- $b]$ indoles have been synthesized from 3-(2-oxo-2-(hetero)arylethylidene)indolin-2one by treatment of the latter with Lawesson's reagent through a tandem reduction of the $\mathrm{C}=\mathrm{C}$ double bond and the Paal-Knorr cyclization, thus affording tricyclic thieno[2,3- $b]$ indoles. In its turn, the required indolin-2-ones have been prepared by a 
simple "aldol-crotonic" type of condensation of $N$-alkylated isatins with acetophenones or their heterocyclic analogues. This two-step approach provides an easy access to compounds of the family of electron-rich thieno[2,3- $b]$ indoles, which are regarded as promising building-blocks for the development of new photo- and electrosensitive molecules, e.g., novel push-pull dyes for dye-sensitized solar cells.

\section{Experimental}

\section{General information}

${ }^{1} \mathrm{H}$ and ${ }^{13} \mathrm{C}$ NMR spectra were obtained on Bruker DRX-400 and AVANCE-500 spectrometers with TMS as the internal standard. Elemental analysis was carried on an Eurovector EA 3000 automated analyzer. Mass spectrometry was performed using a Bruker maXis Impact HD spectrometer. Melting points were determined on Boetius combined heating stages and were not corrected. All solvents used were dried and distilled per standard procedures. IR spectra of samples (solid powders) were recorded on a Spectrum One Fourier transform IR spectrometer (Perkin Elmer) equipped with a diffuse reflectance attachment (DRA). X-ray diffraction analysis was performed on an automated X-ray diffractometer "Xcalibur E" on standard procedure.

\section{General procedure for the synthesis of 3-(2- oxo-2-(hetero)arylethylidene)indolin-2-one $10 a-100$}

The solution of 1-alkylisatin 7 (3 mmol), corresponding methyl ketone 8 ( $3 \mathrm{mmol})$ and $N, N$-diethylamine $(0.062 \mathrm{~mL}, 0.6 \mathrm{mmol})$ in EtOH $(15 \mathrm{~mL})$ was stirred at room temperature for $48 \mathrm{~h}$. The resulting mixture was concentrated under reduced pressure to obtain crude adduct 9 that was dehydrated without any purification according to method A or method B.

Method A (For the preparation of compounds 10a-d, $\mathbf{1 0 g}-\mathbf{k})$ : A drop of hydrochloric acid was added to the suspension of crude adduct 9 in acetic acid $(3 \mathrm{~mL})$. The mixture was stirred at $100{ }^{\circ} \mathrm{C}$ for $30 \mathrm{~min}$. After cooling the precipitate was filtered, washed with methanol and dried to give indolin-2-one $\mathbf{1 0}$ as an orange to dark-red solid.

1-Ethyl-3-(2-oxo-2-phenylethylidene)indolin-2-one (10a): Orange powder; Yield $525 \mathrm{mg}$ (63\%); mp 122-123 ${ }^{\circ} \mathrm{C}$; ${ }^{1} \mathrm{H}$ NMR $\left(500 \mathrm{MHz}, \mathrm{DMSO}-d_{6}\right) \delta 8.08(\mathrm{dd}, J=8.2,0.9 \mathrm{~Hz}$, 2H), $8.00(\mathrm{~d}, J=7.6 \mathrm{~Hz}, 1 \mathrm{H}), 7.79(\mathrm{~s}, 1 \mathrm{H}), 7.73(\mathrm{t}, J=7.4 \mathrm{~Hz}$, $1 \mathrm{H}), 7.61(\mathrm{t}, J=7.8 \mathrm{~Hz}, 2 \mathrm{H}), 7.47-7.40(\mathrm{~m}, 1 \mathrm{H}), 7.13(\mathrm{~d}$, $J=7.9 \mathrm{~Hz}, 1 \mathrm{H}), 7.02(\mathrm{t}, J=7.6 \mathrm{~Hz}, 1 \mathrm{H}), 3.79(\mathrm{q}, J=7.2 \mathrm{~Hz}$, $2 \mathrm{H}), 1.20(\mathrm{t}, J=7.2 \mathrm{~Hz}, 3 \mathrm{H}) ;{ }^{13} \mathrm{C}$ NMR (126 MHz, DMSO- $\left.d_{6}\right)$ $\delta 191.3,166.3,144.8,136.8,135.2,134.1,132.8,129.1,128.6$, 126.8, 126.4, 122.1, 119.4, 109.2, 34.3, 12.5; IR(DRA): 493, $546,577,600,630,674,691,750,779,802,877,894,949$,
$1009,1067,1089,1108,1159,1181,1228,1293,1347,1446$, 1469, 1482, 1578, 1600, 1620, 1658, 1701, 1823, 1921, 2873, 2933, 2975, 3056, $3114 \mathrm{~cm}^{-1}$; anal. calcd for $\mathrm{C}_{18} \mathrm{H}_{15} \mathrm{NO}_{2}$ : C, 77.96; H, 5.45; N, 5.05; found: C, 77.66; H, 5.34; N, 5.08.

Method B (For the preparation of compounds 10e,f,l,-o): $\mathrm{SOCl}_{2}(0.28 \mathrm{ml}, 3.9 \mathrm{mmol})$ was added to the solution of crude adduct 9 in dry $\mathrm{CH}_{2} \mathrm{Cl}_{2}(10 \mathrm{ml})$. The mixture was stirred at room temperature for $2 \mathrm{~h}$. The resulting mixture was concentrated under reduced pressure and the residue was recrystallized in EtOH affording indolin-2-one $\mathbf{1 0}$ as orange to dark-red needles.

1-Ethyl-3-(2-(2-nitrophenyl)-2-oxoethylidene)indolin-2-one (10f): Red crystals; Yield $780 \mathrm{mg}(81 \%)$; mp $120-121{ }^{\circ} \mathrm{C}$; ${ }^{1} \mathrm{H}$ NMR (400 MHz, DMSO- $\left.d_{6}\right) \delta 8.41(\mathrm{~d}, J=7.6 \mathrm{~Hz}, 1 \mathrm{H})$, $8.21(\mathrm{dd}, J=8.1,0.7 \mathrm{~Hz}, 1 \mathrm{H}), 7.97-7.82(\mathrm{~m}, 3 \mathrm{H}), 7.52(\mathrm{td}$, $J=7.8,1.0 \mathrm{~Hz}, 1 \mathrm{H}), 7.33(\mathrm{~s}, 1 \mathrm{H}), 7.16(\mathrm{~d}, J=7.9 \mathrm{~Hz}, 1 \mathrm{H}), 7.11$ $(\mathrm{td}, J=7.7,0.8 \mathrm{~Hz}, 1 \mathrm{H}), 3.77(\mathrm{q}, J=7.2 \mathrm{~Hz}, 2 \mathrm{H}), 1.18(\mathrm{t}$, $J=7.2 \mathrm{~Hz}, 3 \mathrm{H}) ;{ }^{13} \mathrm{C}$ NMR $\left(126 \mathrm{MHz}, \mathrm{DMSO}-d_{6}\right) \delta 191.3$, $166.4,146.2,145.5,136.4,135.8,134.7,133.9,132.2,128.8$, $127.5,125.8,124.6,122.4,119.3,109.3,34.3,12.5$; IR(DRA): 473, 490, 548, 567, 584, 642, 675, 690, 746, 778, 846, 897, 932, $1002,1058,1080,1128,1164,1187,1224,1285,1324,1348$, 1391, 1414, 1464, 1485, 1502, 1584, 1608, 1629, 1653, 1709, 1780, 2648, 2837, 2939, 3021, $3402 \mathrm{~cm}^{-1}$; anal. calcd for $\mathrm{C}_{18} \mathrm{H}_{14} \mathrm{~N}_{2} \mathrm{O}_{4}$ : C, 67.07; H, 4.38; N, 8.69; found: $\mathrm{C}, 67.03 ; \mathrm{H}$, $4.12 ; \mathrm{N}, 8.62$.

\section{Procedure for the one-pot synthesis of thieno[2,3-b]indole 12a}

The solution of $N$-ethylisatin $7 \mathbf{a}(175 \mathrm{mg}, 1 \mathrm{mmol})$ and (phenacylidene)triphenylphosphorane 13 (380 mg, $1 \mathrm{mmol})$ in dry toluene $(5 \mathrm{~mL})$ was stirred at room temperature for $48 \mathrm{~h}$. Afterwards Lawesson's reagent (405 mg, $1 \mathrm{mmol}$ ) was added and the mixture was refluxed for $1 \mathrm{~h}$. The resulting solution was concentrated under reduced pressure and the residue was dissolved in $\mathrm{CH}_{2} \mathrm{Cl}_{2}$ and filtered through a silicagel pad. After evaporation of $\mathrm{CH}_{2} \mathrm{Cl}_{2}$ the crude product was purified by recrystallization from EtOH giving thieno[2,3-b]indoles 12a as white needles in $54 \%$ yield $(150 \mathrm{mg})$.

\section{General procedure for the synthesis of thieno[2,3-b]indoles 12a-120}

The mixture of indolin-2-one $\mathbf{1 0}(2 \mathrm{mmol})$ and the Lawesson reagent $(0.81 \mathrm{~g}, 2 \mathrm{mmol})$ in dry toluene $(10 \mathrm{~mL})$ was refluxed for $1 \mathrm{~h}$. Upon refluxing the color of the solution turns from dark-red to yellowish. The resulting solution was concentrated under reduced pressure and the residue was dissolved in $\mathrm{CH}_{2} \mathrm{Cl}_{2}$ and filtered through a silicagel pad. After evaporation of $\mathrm{CH}_{2} \mathrm{Cl}_{2}$ the crude product was purified by recrystallization in 
EtOH affording thieno[2,3-b]indoles 12 as white to yellow needles.

8-Ethyl-2-phenyl-8H-thieno[2,3-b]indole (12a): Pale yellow needles; Yield $500 \mathrm{mg}(90 \%)$; $\mathrm{mp} 82-83{ }^{\circ} \mathrm{C}$; ${ }^{1} \mathrm{H}$ NMR $\left(500 \mathrm{MHz}, \mathrm{CDCl}_{3}\right) \delta 7.81(\mathrm{~d}, J=7.8 \mathrm{~Hz}, 1 \mathrm{H}), 7.67-7.57(\mathrm{~m}$, $3 \mathrm{H}), 7.42-7.33(\mathrm{~m}, 3 \mathrm{H}), 7.30-7.26(\mathrm{~m}, 1 \mathrm{H}), 7.25-7.21(\mathrm{~m}, 1 \mathrm{H})$, $7.21-7.16(\mathrm{~m}, 1 \mathrm{H}), 4.28(\mathrm{q}, J=7.3 \mathrm{~Hz}, 2 \mathrm{H}), 1.52(\mathrm{t}, J=7.3 \mathrm{~Hz}$, $3 \mathrm{H}) ;{ }^{1} \mathrm{H}$ NMR (500 MHz, DMSO- $\left.d_{6}\right) \delta 7.92(\mathrm{~s}, 1 \mathrm{H}), 7.82(\mathrm{~d}$, $J=7.7 \mathrm{~Hz}, 1 \mathrm{H}), 7.66(\mathrm{~d}, J=7.3 \mathrm{~Hz}, 2 \mathrm{H}), 7.58(\mathrm{~d}, J=8.2 \mathrm{~Hz}$, $1 \mathrm{H}), 7.44-7.36(\mathrm{~m}, 2 \mathrm{H}), 7.28-7.21(\mathrm{~m}, 2 \mathrm{H}), 7.19-7.11(\mathrm{~m}, 1 \mathrm{H})$, 4.34 (q, $J=7.2 \mathrm{~Hz}, 2 \mathrm{H}), 1.40(\mathrm{t}, J=7.2 \mathrm{~Hz}, 3 \mathrm{H}) ;{ }^{13} \mathrm{C} \mathrm{NMR}$ $\left(126 \mathrm{MHz}, \mathrm{DMSO}-d_{6}\right) \delta 141.6,140.8,135.0,134.8,129.1$, $126.7,124.5,123.4,122.0,121.5,119.4,119.1,114.8,109.9$, 40.3, 13.6; IR(DRA): 474, 550, 567, 688, 746, 779, 835, 850, $905,935,999,1015,1049,1078,1100,1131,1162,1191,1207$, $1252,1330,1350,1377,1393,1409,1439,1477,1496,1524$, 1595, 1671, 1734, 1776, 1867, 1894, 1942, 2888, 2928, 2972, 3029, 3053, $3748 \mathrm{~cm}^{-1}$; MS (+APCI): Calcd. for $\mathrm{C}_{18} \mathrm{H}_{15} \mathrm{NS} \mathrm{m} / \mathrm{z}$ $278.0998[\mathrm{M}+\mathrm{H}]$, found $\mathrm{m} / \mathrm{z} 278.1000[\mathrm{M}+\mathrm{H}]$; Crystal data for $12 \mathrm{a}$ : Colorless crystals $0.24 \times 0.19 \times 0.13 \mathrm{~mm}$, $\theta<25.6080^{\circ}, 11563$ reflections were collected, 7249 independent reflections $\left(R_{\text {int }} 0.0245\right)$, completeness $100 \%$. Crystal is monoclinic, space group Cc, $a=19.0695(13) \AA$, $b=30.6399(16) \AA, c=7.8360(4) \AA, \alpha=90.00^{\circ}$, $\beta=106.777(6)^{\circ}, \gamma=90.00^{\circ}, \mu=0.210 \mathrm{~mm}^{-1}$. The SHELXTL program [35] was used for solution and structure refinement. Refinement and the final $R$ indices: $R_{1}=0.0432[\mathrm{I}>2 \sigma(\mathrm{I})]$, $\mathrm{wR}_{2}=0.1050[\mathrm{I}>2 \sigma(\mathrm{I})], R_{1}=0.0772$ (all data), $\mathrm{w} R_{2}=0.1355$ (all data), $S=1.004$. Deposition number CCDC 1054153 contains the supplementary crystallographic data for this structure. These data can be obtained free of charge from the Cambridge Crystallographic Data Centre via http:// www.ccdc.cam.ac.uk/data_request/cif.

\section{8-Ethyl-2-(2-nitrophenyl)-8H-thieno[2,3- b]indole (12f)}

Yellow powder; Yield $530 \mathrm{mg}$ (82\%); mp 103-104 ${ }^{\circ} \mathrm{C}$; ${ }^{1} \mathrm{H}$ NMR (400 MHz, DMSO- $\left.d_{6}\right) \delta 7.94(\mathrm{~d}, J=7.8 \mathrm{~Hz}, 1 \mathrm{H})$, $7.87(\mathrm{~d}, J=7.8 \mathrm{~Hz}, 1 \mathrm{H}), 7.77-7.71(\mathrm{~m}, 2 \mathrm{H}), 7.67-7.53(\mathrm{~m}, 3 \mathrm{H})$, $7.33-7.27(\mathrm{~m}, 1 \mathrm{H}), 7.22-7.13(\mathrm{~m}, 1 \mathrm{H}), 4.37$ (q, $J=7.2 \mathrm{~Hz}, 2 \mathrm{H})$, $1.41(\mathrm{t}, J=7.2 \mathrm{~Hz}, 3 \mathrm{H}) ;{ }^{13} \mathrm{C}$ NMR $\left(126 \mathrm{MHz}, \mathrm{DMSO}-d_{6}\right) \delta$ $148.9,143.0,140.8,132.5,131.7,128.6,127.6,127.0,123.9$, $123.3,122.4,121.3,119.6,119.4,118.7,110.0,40.4,13.5$; IR(DRA): 482, 549, 567, 584, 646, 662, 685, 700, 738, 746, $770,834,845,861,919,941,953,986,1015,1052,1084,1134$, $1162,1204,1251,1267,1283,1296,1331,1375,1399,1411$, $1439,1464,1484,1532,1570,1599,1652,1751,1788,1836$, 1871, 1909, 1936, 1969, 2332, 2736, 2889, 2936, 2974, 2989, $3075,3058 \mathrm{~cm}^{-1}$; Anal. calcd for $\mathrm{C}_{18} \mathrm{H}_{14} \mathrm{~N}_{2} \mathrm{O}_{2} \mathrm{~S}$ : C, 67.06; $\mathrm{H}$, 4.38; N, 8.69; found: C, 66.98; H, 4.35; N, 8.72.

\section{Supporting Information}

\section{Supporting Information File 1}

Analytical data and copies of the ${ }^{1} \mathrm{H}$ and ${ }^{13} \mathrm{C}$ NMR spectra of the new compounds.

[http://www.beilstein-journals.org/bjoc/content/ supplementary/1860-5397-11-112-S1.pdf]

\section{Acknowledgements}

This work was supported by the Russian Foundation for Basic Research (research projects No. 13-03-12434-ofi_m2, 13-0396049-r_ural_a, 14-03-01017_A, 15-03-00924_A) and the Scientific Council of the President of the Russian Federation (grant MK-3043.2014.3).

\section{References}

1. Engqvist, R.; Javaid, A.; Bergman, J. Eur. J. Org. Chem. 2004, 2589-2592. doi:10.1002/ejoc.200400073

2. Kanbe, K.; Naganawa, H.; Okamura, M.; Okami, Y.; Takeuchi, T.; Hattori, S.; Hamada, M. Biosci., Biotechnol., Biochem. 1993, 57, 632-635. doi:10.1271/bbb.57.632

3. Kanbe, K.; Naganawa, H.; Nakamura, K. T.; Okami, Y.; Takeuchi, T. Biosci., Biotechnol., Biochem. 1993, 57, 636-637. doi:10.1271/bbb.57.636

4. Jakobsen, P.; Kanstrup, A.; Faarup, P.; Olesen, P.; Lundbech, J. Antagonists, their preparation and use. U.S. Patent $5,783,575$, June 21, 1998.

5. An-naka, M.; Yasuda, K.; Yamada, M.; Kawai, A.; Takamura, N.; Sugasawa, S.; Matsuoka, Y.; Iwata, H.; Fukushima, T. Heterocycles 1994, 39, 251-270. doi:10.3987/COM-94-S(B)20

6. Karthikeyan, S. V.; Perumal, S.; Shetty, K. A.; Yogeeswari, P.; Sriram, D. Bioorg. Med. Chem. Lett. 2009, 19, 3006-3009. doi:10.1016/j.bmcl.2009.04.029

7. Zhan, Z.-J.; Bian, H.-L.; Wang, J.-W.; Shan, W.-G. Bioorg. Med. Chem. Lett. 2010, 20, 1532-1534. doi:10.1016/j.bmcl.2010.01.097

8. Irgashev, R. A.; Karmatsky, A. A.; Kozyukhin, S. A.; Ivanov, V. K.; Sadovnikov, A.; Kozik, V. V.; Grinberg, V. A.; Emets, V. V.; Rusinov, G. L.; Charushin, V. N. Synth. Met. 2015, 199, 152-158. doi:10.1016/j.synthmet.2014.11.024

9. Qi, T.; Qiu, W.; Liu, Y.; Zhang, H.; Gao, X.; Liu, Y.; Lu, K.; Du, C.; Yu, G.; Zhu, D. J. Org. Chem. 2008, 73, 4638-4643. doi:10.1021/j0800622y

10. Qi, T.; Guo, Y.; Liu, Y.; Xi, H.; Zhang, H.; Gao, X.; Liu, Y.; Lu, K.; Du, C.; Yu, G.; Zhu, D. Chem. Commun. 2008, 6227-6229. doi:10.1039/b813683a

11. Du, C.; Chen, J.; Guo, Y.; Lu, K.; Ye, S.; Zheng, J.; Liu, Y.; Shuai, Z.; Yu, G. J. Org. Chem. 2009, 74, 7322-7327. doi:10.1021/jo901381f

12. Balaji, G.; Valiyaveettil, S. Org. Lett. 2009, 11, 3358-3361. doi:10.1021/ol901133m

13. Donaghey, J. E.; Ashrarf, R. S.; Kim, Y.; Huang, Z. G.; Nielsen, C. B.; Zhang, W.; Schroeder, B.; Grenier, C. R. G.; Brown, C. T.; D'Angelo, P.; Smith, J.; Watkins, S.; Song, K.; Anthopoulos, T. D.; Durrant, J. R.; Williams, C. K.; McCulloch, I. J. Mater. Chem. 2011, 21 , 18744-18752. doi:10.1039/c1jm13428k 
14. Xiong, Y.; Wu, Q.; Li, J.; Wang, S.; Gao, X.; Li, H. J. Org. Chem. 2013, 78, 752-756. doi:10.1021/jo3022154

15. Wetzel, C.; Mishra, A.; Mena-Osteritz, E.; Liess, A.; Stolte, M.; Würthner, F.; Bäuerle, P. Org. Lett. 2014, 16, 362-365. doi:10.1021/ol403153z

16. Anthony, J. E. Chem. Rev. 2006, 106, 5028-5048. doi:10.1021/cr050966z

17. Meyer, A.; Sigmund, E.; Luppertz, F.; Schnakenburg, G.; Gadaczek, I.; Bredow, T.; Jester, S.-S.; Höger, S. Beilstein J. Org. Chem. 2010, 6, 1180-1187. doi:10.3762/bjoc.6.135

18. Mason, C. R.; Li, Y.; O'Brien, P.; Findlay, N. J.; Skabara, P. J. Beilstein J. Org. Chem. 2011, 7, 1722-1731. doi:10.3762/bjoc.7.202

19. Cortizo-Lacalle, D.; Howells, C. T.; Pandey, U. K.; Cameron, J.; Findlay, N. J.; Inigo, A. R.; Tuttle, T.; Skabara, P. J.; Samuel, I. D. W. Beilstein J. Org. Chem. 2014, 10, 2683-2695. doi:10.3762/bjoc.10.283

20. Otani, T.; Kunimatsu, S.; Takahashi, T.; Nihei, H.; Saito, T. Tetrahedron Lett. 2009, 50, 3853-3856. doi:10.1016/j.tetlet.2009.04.045

21. Singh, P. P.; Yadav, A. K.; Ila, H.; Junjappa, H. Eur. J. Org. Chem. 2011, 4001-4007. doi:10.1002/ejoc.201100516

22. Yadav, A. K.; Ila, H.; Junjappa, H. Eur. J. Org. Chem. 2010, 338-344. doi:10.1002/ejoc.200901036

23. Kienle, M.; Wagner, A. J.; Dunst, C.; Knochel, P. Chem. - Asian J. 2011, 6, 517-523. doi:10.1002/asia.201000367

24. Butin, A. V.; Tsiunchik, F. A.; Abaev, V. T.; Zavodnik, V. E. Synlett 2008, 1145-1148. doi:10.1055/s-2008-1072720

25. Appukkuttan, P.; Van der Eycken, E.; Dehaen, W. Synlett 2005, 127-133. doi:10.1055/s-2004-836030

26. Smitrovich, J. H.; Davies, I. W. Org. Lett. 2004, 6, 533-535. doi:10.1021/ol036294I

27. Boeini, H. Z. Helv. Chim. Acta 2009, 92, 1268-1272. doi:10.1002/hlca.200800423

28. Savych, I.; Gläsel, T.; Villinger, A.; Sosnovskikh, V. Ya.; laroshenko, V. O.; Langer, P. Org. Biomol. Chem. 2015, 13, 729-750. doi:10.1039/C4OB01730G

29. Beccalli, E. M.; Marchesini, A.; Pilati, T. Tetrahedron 1993, 49, 4741-4758. doi:10.1016/S0040-4020(01)81301-6

30. Albertshofer, K.; Tan, B.; Barbas, C. F., III. Org. Lett. 2012, 14, 1834-1837. doi:10.1021/ol300441z

31. Cao, S.-H.; Zhang, X.-C.; Wei, Y.; Shi, M. Eur. J. Org. Chem. 2011 2668-2672. doi:10.1002/ejoc.201100017

32. Levy, J.; Royer, D.; Guilhem, J.; Cesario, M.; Pascard, C. Bull. Soc. Chim. Fr. 1987, 193-198.

33. Kobayashi, G.; Furukawa, S.; Matsuda, Y.; Natsuki, R. Yakuguku Zasshi 1969, 89, 58-63.

34. Mercury 3.1 is available from http://www.ccdc.cam.ac.uk/mercury/.

35. Sheldrick, G. M. Acta Crystallogr., Sect. A 2008, 64, 112-122. doi:10.1107/S0108767307043930

\section{License and Terms}

This is an Open Access article under the terms of the Creative Commons Attribution License

(http://creativecommons.org/licenses/by/2.0), which permits unrestricted use, distribution, and reproduction in any medium, provided the original work is properly cited.

The license is subject to the Beilstein Journal of Organic Chemistry terms and conditions:

(http://www.beilstein-journals.org/bjoc)

The definitive version of this article is the electronic one which can be found at:

doi:10.3762/bjoc. 11.112 